Int. J. Electrochem. Sci., 12 (2017) $6031-6044$

International Journal of

ELECTROCHEMICAL

SCIENCE

www.electrochemsci.org

\title{
A label-free Electrochemical DNA Biosensor for the Determination of Low Concentrations of Mitoxantrone in Serum Samples
}

\author{
Azam Torkzadeh-Mahani ${ }^{1,2}$, Abbas Mohammadi $^{2}$, Masoud Torkzadeh-Mahani $^{3,{ }^{*}}$, Maryam Mohamadi ${ }^{4}$ \\ ${ }^{1}$ Student Research Committee, School of Medicine, Kerman University of Medical Sciences, Kerman, \\ Iran \\ ${ }^{2}$ Department of Clinical Biochemistry, Afzalipour School of Medicine, Kerman University of Medical \\ Sciences, Kerman, Iran. \\ ${ }^{3}$ Department of Biotechnology, Institute of Science, High Technology and Environmental Sciences, \\ Graduate University of Advanced Technology, Kerman, Iran \\ ${ }^{4}$ Pistachio Safety Research Center, Rafsanjan University of Medical Sciences, Rafsanjan, Iran \\ *E-mail: mtmahani@gmail.com
}

doi: $10.20964 / 2017.07 .02$

Received: 10 January 2017 / Accepted: 18 April 2017 / Published: 12 June 2017

Herein, a sensitive, accurate and precise DNA biosensor for the quantification of low levels of mitoxantrone in serum samples was presented. This approach is based on the interaction of the drug with double-stranded DNA and subsequent electrochemical transduction. Chitosan as a positive polymer was used for the immobilization of the DNA on the surface of a carbon paste electrode (working electrode). After optimization of different experimental parameters, the proposed biosensor showed a wide concentration linear range of $0.030-3.50 \mathrm{mg} \mathrm{L}^{-1}$ and $3.50-120.0 \mathrm{mg} \mathrm{L}^{-1}$ with a detection limit of $0.0013 \mathrm{mg} \mathrm{L}^{-1}$. It was found that the optimized approach could be applied to the determination of mitoxantrone in serum samples with acceptable recovery values.

Keywords: Mitoxantrone, DNA biosensor, Voltammetry, Chitosan

\section{$\underline{\text { FULL TEXT }}$}

(C) 2017 The Authors. Published by ESG (www.electrochemsci.org). This article is an open access article distributed under the terms and conditions of the Creative Commons Attribution license (http://creativecommons.org/licenses/by/4.0/). 